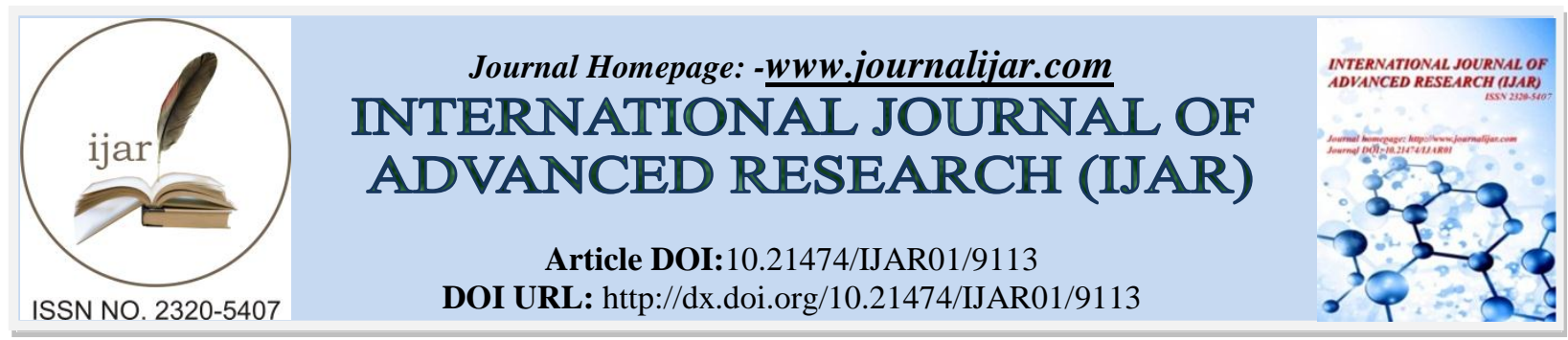

RESEARCH ARTICLE

\title{
EFFECT OF SINGLE SUPER PHOSPHATE ON HISTOPATHOLOGICAL ASPECTS OF FISH CHANNA STRIATUS.
}

T.Madhulatha ${ }^{1}$ and M. Rajyasree ${ }^{2}$.

1. Department of Zoology Dravidian University (off Campus), Kuppam -517425. A. P.

2. Department of Zoology, Vivek Vardhini College of Arts Commerce, Science and Post Graduate Studies, Jambagh, Hyderabad-500095.T.S.

\section{Manuscript Info}

Manuscript History

Received: 22 March 2019

Final Accepted: 24 April 2019

Published: May 2019

\section{Abstract}

The present study was conducted on 12 fish divided into 2 groups the control and experimental. Experimental fish were given SSP, dissolved in water $400 \mathrm{mg} / \mathrm{l}(\mathrm{wt} / \mathrm{vol})$. Recorded observations revealed that the fish tissues liver, gill and kidney cyto architectural changes at the end of 15 days of exposure to SSP, damage at tissue level leading to abnormalities in histology and there was not much change in controls

Copy Right, IJAR, 2019,. All rights reserved.

\section{Introduction:-}

Histopathology deals with the study of pathological changes induced in the microscopic structure of the body tissues. Any change in cells may indicate presence of disease caused by infections, pollutants, or toxicants. Thus the study of histopathology is important in the diagnosis and prevention of diseases. In fishes it is observed that internal and external organs are affected due to many pollutants causing loss of equilibrium, increase in gill opercular moments leading to even death. Thus histo pathological study can be considered as one of the important tools in assessing the toxic effects of chemicals. Histological techniques have been used to evaluate unknown effects of heavy metals, fertilizers in the aquatic ecosystems (Roberts 2001, Riba et.al, 2005, Altinok and Capkin (2007). Histo pathological biomarkers can be the indicators of anthropogenic, activities. Pollutant effects on organism are reflection of the overall health of the entire population in the aquatic ecosystem. The alternations in cells and tissues in fish are recurrently used as biomarkers in many studies. The histopathology provides information to detect effects of irritants in various organs (Johnson et. al, 1993). Exposure of fish to chemical contaminants is likely to induce a number of lesions in different organs. Gills, Kidney, Liver are suitable organs for histological examination in order to determine the effect of pollution. Reports on toxicity of inorganic fertilizers are available and are given as chronic exposure to ammonia can damage liver, gills and kidney (Flis-1968). Fish liver histopathology is an indicator of general health condition of fish and levels of toxic effects. Liver of fish is responsible for digestion, filteration and storage of glycogen (Atif, Naggar 2009). Liver also produces many enzymes that stored in the gall bladder, and also helps in the storage of energy (Tayel, et. al. 2008). The normal liver is made up of condensed mass of hepatocytes arranged in irregular cells which are polygonal in shape with distinct nuclei large numbers of blood sinusoids were also present around the hepatocytes .control liver section of fish showed hepatocyte and other cells systematically arranged.

Thus in the present study after exposing fish to sub lethal concentration $400 \mathrm{mg} / \mathrm{l}$ of single super phosphate (SSP) fertilizer histological alterations were studied. 


\section{Material and Methods:-}

Channa striatus weighing approximately $650 \mathrm{~g}$ - $700 \mathrm{~g}$ were obtained from a standard reputed fish farm of Rajendranagar, Hyderabad T.S India. 2 different groups of 12 fish in each group were maintained as, group I control and group II as experimental exposed to $400 \mathrm{mg} / \mathrm{l}(\mathrm{w} / \mathrm{v})$ SSP (dissolved in water) for 15 days. The fish were maintained under laboratory condition in a controlled environment. The fish were kept at $30^{\circ} \pm 2^{\circ} \mathrm{C}$ temperature and perfect conditions of aeration.. To study the histological changes in liver, gill and kidney, after stipulated period of exposure toSSP, tissues were dissected out from control and experimental fishes and were fixed in biuon's fluid. The tissue samples were then processed routinely for paraffin embedding technique. Embedded tissues were sectioned at $6 \mu$ and stained with haematoxylin and eosin as per the method of Woods and Ellis (1994). The stained sections were examined under high power microscope and micro photographed (110x)

\section{Results and Discussion:- \\ Histopathology}

Fig 1 : Section of Liver demonstrating the normal Hepatocytes and Synusoids (H \& E X 110.

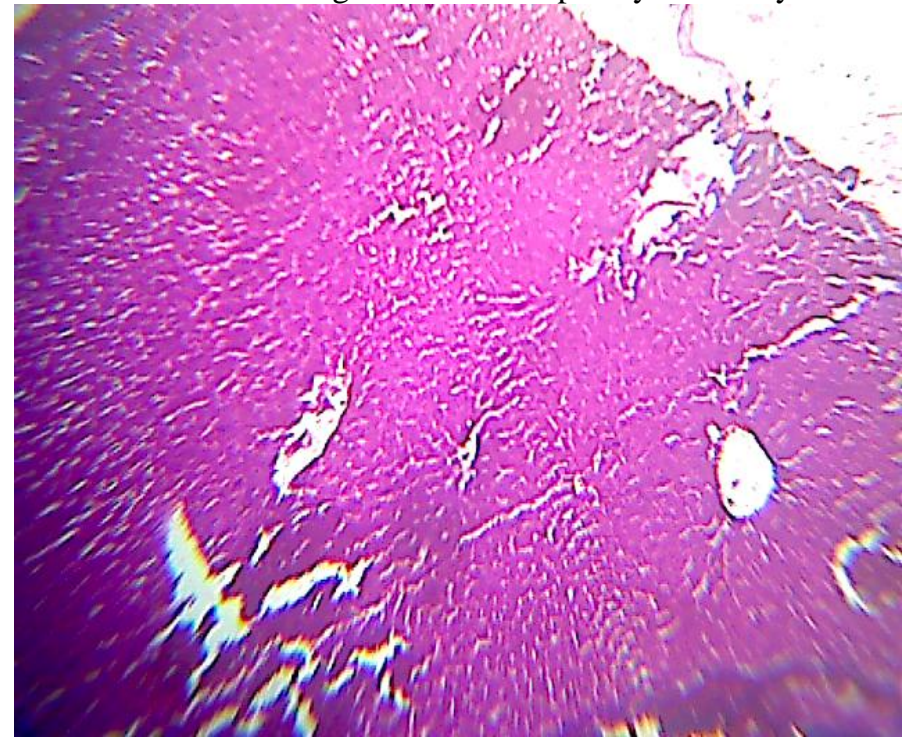

Fig 2: Section of Liver exposed to single super phosphate showing degeneration of heptocytes and distorsion of

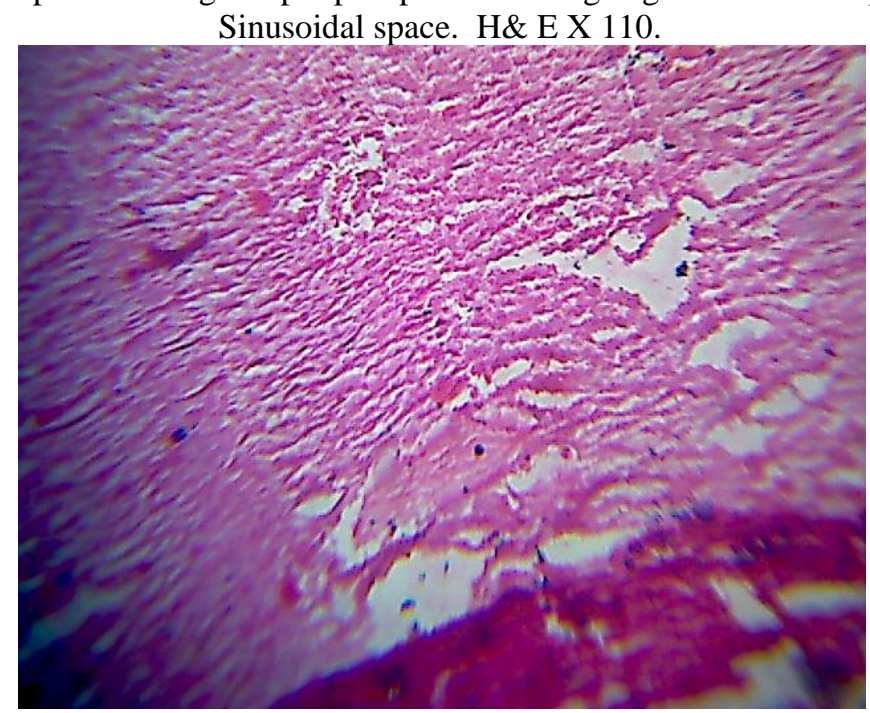


Fig 3 : Section of normal gill showing gill rachis primary gill lamellae and secondary gill lamellae. H\& E X 110.

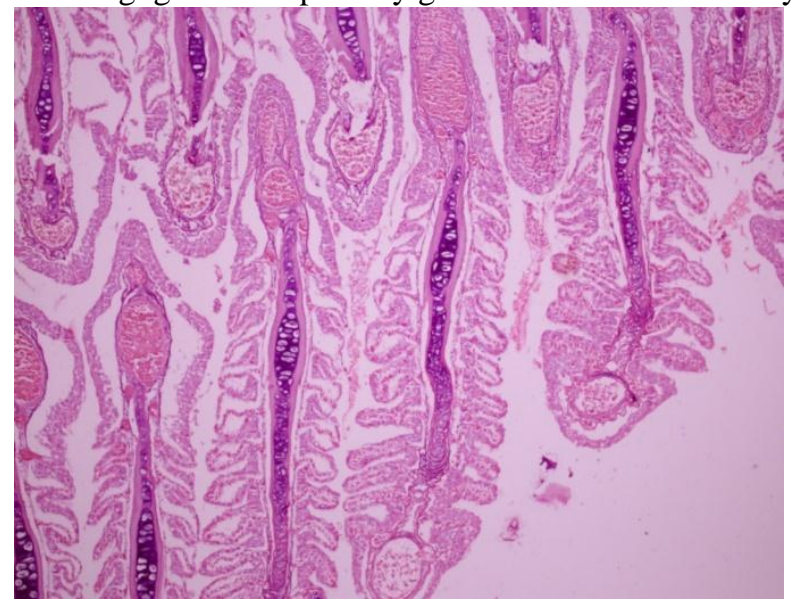

Fig 4 : Section of gill showing changes in gill rachis, primary gill lamellae, and secondary gill lamellae exposed to single super phosphate. H\& E X 110.

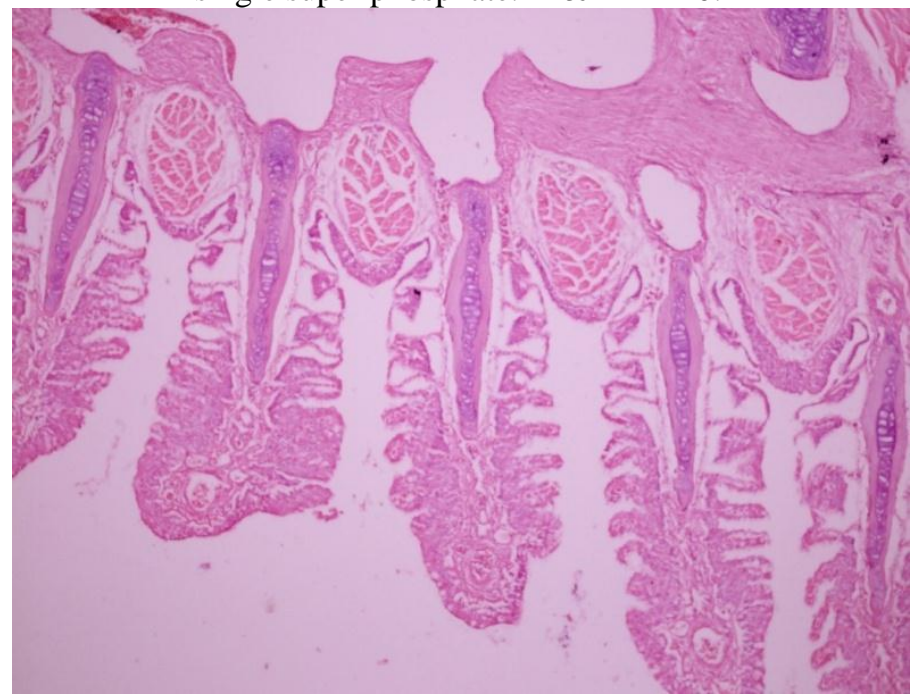

Fig 5: Section of normal renal tissue with glomuerulus and renal tubules H\& E X 110

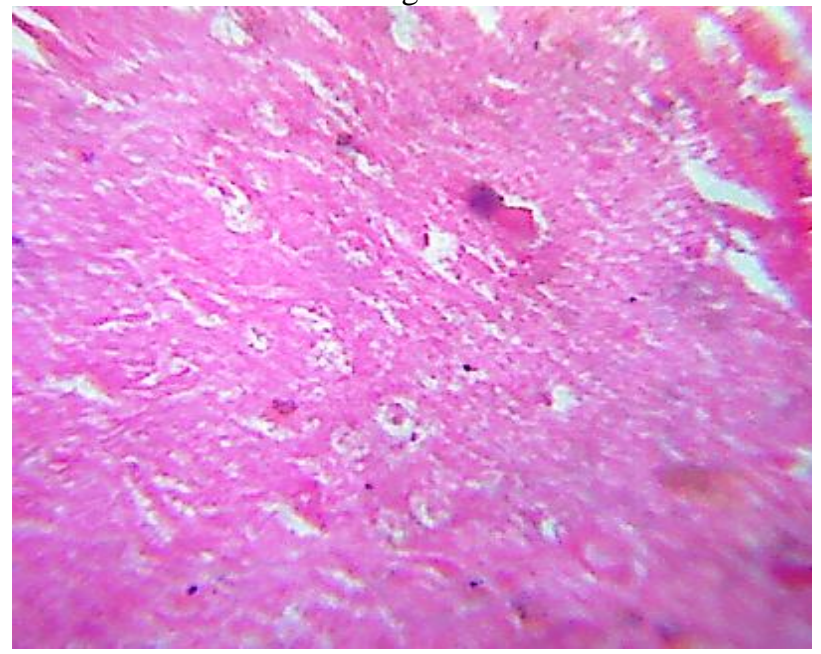


Fig 6: Section of normal renal tissue glomuerulus and renal tubules H\& E X 110

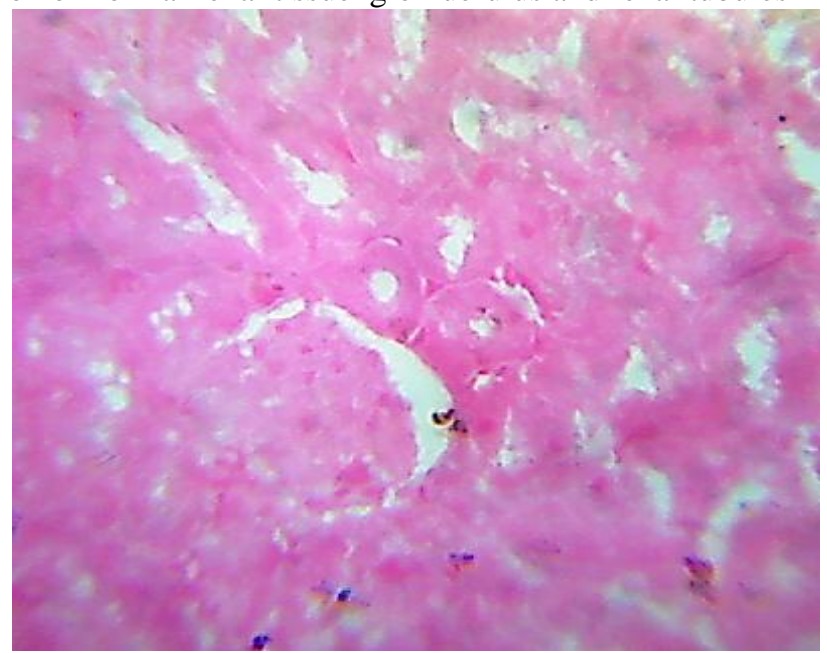

\section{Result And Discussion:-}

The over all observed results in the present investigation indicated marked histopathological changes in liver, gill, and kidney of fish exposed to sub lethal concentrations of single super phosphate. After exposing fish to fertilizer SSP, histological lesions were observed in all the three tissues.

In case of liver the control liver exhibited normal structure and systematic arrangement of hepatocytes, where as treated fish liver exhibited rupture of blood vessels, piknosis, mild necrosis and vacuolization.

Similarly normal structure of kidney cells were observed in control fishes where as SSP treated kidney cells exhibited alternations such as vacuolation, degeneration of kidney tubules and haematopoitic cells, necrosis and hemorrhages.

The sections of gill showed normal structure with filament and cartilagenous gill bar and secondary lamellae. The ssp treated fish gills exhibited edema of gills, changes in secondary lamellae and primary lamella along with loss of epithelial cells. Histopathological changes in fish gills were used as bio-monitoring effects of various aquatic pollution. The pathological alterations in the present study showed erosion of gill matting of gill filaments, necrosis and vascular congestion.

Similar studies were observed in cat fish exposed to fertilizer ammonium sulphate (Paul and Bannerjee 1997), according to this study cat fish exposed to Ammonium sulphate, exhibited corrosive action of inorganic fertilizer on opercular linings. And it was also observed alternations such as hyperplasia of epithelial cells.

Appearance of vacuoles in the hepato cytes of fish were reported by (Matton and Lehman 1969; Smith and Piper, 1975) when fish exposed to pesticides, similarly (Martino 1973) reported Vacuolation or degeneration of liver cells in anabas fish when exposed to furadan.

Barak Zebedee, et. al, (2015) reported exposure of fingerlings of clarius to waste water from super phosphate fertilizer company exhibited histopathological alternations in gills such as altered primary lamellae, loss of secondary lamellae, and erosion of villi in liver he has reported fatty degeneration edema necrosis and the observations were prominent during highest concentrate exposure. Cengis et .al, (2001) reported changes in liver tissues of mosquito fish Gambusia on exposure to endosulphon.

Deori and Wagh( 2012) studied histopathological changes liver of fish Channa gachua and observed vacuolation in cytoplasm, degeneration of nuclei, vacuolation in stroma, cloudy swelling necrosis rupture of blood sinusoids and loss of shape of hepatocytes and severity of damage were found to be dose dependent of time of exposure of heavy metal. 
As per the reports of (Shaik Salahuddin et.al 2014) fresh water fish oreochromis mosambicus exposed to Ammonium sulphate for 30 days inhibited fusion of gill lamellae, Hypertrophy and degeneration of epithelium of gill, and vacuolation generation of hepatocyte and disintegration of cell boundaries of hepathocytes were prominently observed.

Atif Nagger (2009) reported Histo pathological alterations in liver of Oreochromis niloticus exposed to heavy metals, causing congesion and branching, anastamosis, hemorrhage, haemolysis of liver tissue.

Butchiram, et.al (2009) reported histopathological changes in liver, gill and kidney and Channa punctatus exposed to herbicides alachlor showed gill necrosis fusion and atrophy of primary and secondary gill lamellae. Tissue damages like formation of vacuoles rupture of blood vessels, deposition of hepatic chords of liver, changes in kidney, leading to necrosis, swelling of renal tubules and cellular Hypertrophy.

Olojo et. al (2005) reported African cat fish Clarius garietinus exposed to lead showed histopathological changes of gill and liver tissues and from his results it was observed that distortion of gill, liver was proportional to exposure period and concentrations of the metal lead used in his experiment. He has also reported progressive architectural distortion in gill tissue, along with degeneration of epithelial cells followed by arterial rupture and ischemia and the activity of fishes were totally slowed down due to damage of gill tissue.

\section{Acknowledgement:-}

The first author thanks Dr.M.Rajyasree supervisor, Principal and Management of Vivek Vardhini College of Arts, Commerce, Science and P.G. Studies, Jambagh, Hyderabad. T.S. for providing lab facility and support.

\section{Reference:-}

1. Atif,, M.E., Naggar, Soaad, A. Mahmoud and Safaa, I. Tayel. (2009). Bioaccumulation of some heavy metels and histopathological alterations in liver of Oreochromis niloticus in Relation to water quality at different localities along the River Nile. Egypt. World Journal of Fish and Marine Sciences I (2): 105-114

2. Bark Zebedee, Auta Jehu, Bingari, Mathias Simon, Babale Musa Yoane. (2015). Histopathological studies of Gills and Liver of Clarias Gariepinus cultured in waste water for uperphosphate fertilizer company (SFC). IJSRSET. Vol. 1, ISSN: 2395-1990.

3. Butchiram, K.S. Tilak and Raju, P.W. (2009). Studies on histopathological changes in the gill, liver and kidney of channa punctatus (Bloch) exposed to Alachlor. J. Environ. Biol. 30(2), 303-306.

4. Cengis, E.I., E and Balei, K. (2001). The Histopathological effects of Thiodan on the Liver and gut of mosquito fish, Gambusia affins. Journal of Env.Sci. and Health Part B; pesticides food contaminants and agricultural wastes. Taylor and Francis 36(1) 75-85.

5. Matton, and Lahman, O.N. (1969). Effects of the organophoplate Dylox on I. Rainbow. Trout Larval. J. Fish Res. Bgard can 26.2193-2200.

6. Martin, K.R. (1973). Pathological changes observed in fishes following poisoning by granulated insecticides. Altrazine and Divron Rapid determination of the toxicity of low concentration of pesticides. Mauchnolsslod Inst. Rybn Knoz 26: 245-249.

7. Paul, V.I., and Banerjee, T.K. (1997). Histopathological changes induced by anbient ammonia (ammonium sulphate) on the opercular linings of the catfish heteropneustes fossils Disc of Aqua org. Vol. 28. 151-161. 199).

8. Olojo, E.A.A., Olurin, K.B., Mbaka, G. and Oluwemimo, A.D. (2005). Histopathology of gill and liver tissues of the African catfish Clarias gariepinus exposed to lead. African Journal of Biotechnology Vol.4 (1). Pp. 117-122.

9. Roberts, R.J. (2001). Fish pathology, W.B. Saunders Philadelphia.

10. Shaik, Md., Salahuddin, et al. B., Geetha, R., Muthu Kumaravel, K., and Kumaraswamy, P. (2014). Impact of fertilizer ammonium sulphate on the histology of gill and liver of freshwater fish oveochromis mossabicus. Ind. Journal of Current Research Vol.6 Issue 01.pp4739-4742.

11. Smith, C.E., and Piper, R.G. (1975). Lesions associated with chronic exposure to ammonia. In the pathology of fish leds .W.E. Rubelin and G. Migaki) Univ of Wis press. Madison pp: 497-514.

12. Taylor and Fr Deori, S.V. Wagh, S.B. (2012). Heavy metal induced histopathological alterations in liver of channa gachua (Ham) Journal of experimental sciences 3(3) 35-38. 